\title{
The influence of Boron on pepper plants nutritional status and nutrient efficiency
}

Eleana Sarafi ${ }^{1}$, Anastasios Siomos ${ }^{1}$, Pavlos Tsouvaltzis ${ }^{1}$, Ioannis Therios ${ }^{1}$, Christos

Chatzissavvidis ${ }^{2}$

${ }^{1}$ Department of Horticulture, Aristotle University, 54124, Thessaloniki, Greece. ${ }^{2}$ Department of Agricultural Development, Democritus University of Thrace, 68200 Orestiada, Greece. *Corresponding author: esarafi@ agro.auth.gr

\begin{abstract}
Boron may affect total uptake of various nutrients and their nutrient use efficiency (NUE) which results in high productivity and low fertilizer cost. Therefore, the objective of this study was to investigate the effect of boron concentration in nutrient solution on total uptake of the various nutrients and their utilization efficiency in pepper plants (Capsicum annuum L.). Four cultivars (Osho, Solario, Odysseo and Arlequin) were treated with 0.5-10 $\mathrm{mg} \mathrm{B} \mathrm{L}^{-1}$. Each treatment included five replications with 3 plants and after 20, 40 and 70 days in culture one plant per pot was removed, divided into leaves, shoots and roots and analysed. The cultivars Odysseo and Arlequin have the greatest total phosphorus absorption at $0.5-2.5 \mathrm{mg} \mathrm{B} \mathrm{L}^{-1}$ and more Ca at 1-2.5 $\mathrm{mg} \mathrm{B} \mathrm{L}^{-1}$, while Odysseo absorbed more magnesium $(\mathrm{Mg})$ per plant at $1 \mathrm{mg} \mathrm{B} \mathrm{L}^{-1}$ and $70 \mathrm{~d}$ per plant than the other cultivars. Furthermore, Solario, Odysseo, and Arlequin absorbed at 70 days more B. Differences were recorded also among the cultivars concerning the rest of the nutrients. The maximum nutrient use efficiency of Solario and Osho for phosphorus and potassium was recorded at $5 \mathrm{mg} \mathrm{B} \mathrm{L}^{-1}$, and in Solario for calcium. Boron use efficiency was maximum for Solario, Osho and Odysseo at $0.5 \mathrm{mg} \mathrm{B} \mathrm{L}^{-1}$ and for Fe at $10 \mathrm{mg} \mathrm{B} \mathrm{L}^{-1}$ for all the cultivars. The effect of boron on magnesium, manganese and zinc use efficiency was variable.
\end{abstract}

Keywords: Antagonism, boron, cultivar, macronutrients, micronutrients 


\section{Introduction}

Pepper (Capsicum annuum L.) is a valuable crop not only because of its economic significance but also of the nutritional value of its fruits, which are a major source of antioxidants (Sarafi et al., 2017) and minerals. A proportion greater than $25 \%$ of the worlds' population consumes peppers every day (d) (Namiki, 1990). Ogunlade et al. (2012) reported the general order of mineral content in some pepper cultivars (cvs) as following: $\mathrm{P}$ (phosphorus) $>\mathrm{K}$ (potassium) $>\mathrm{Na}$ $($ sodium $)>\mathrm{Ca} \quad$ (calcium) $>\mathrm{Mg} \quad$ (magnesium) $>\mathrm{Mn}$ (manganese) $>\mathrm{Fe}$ (iron) $>\mathrm{Zn}$ (zinc).

Boron (B) concentration of soils is variable in many areas of the world and in some circumstances toxic B accumulation in the soil or in the irrigation water is frequent. Furthermore, industrial pollution may also play an important role in increased B level of agricultural soils (Nable et al., 1997) which above the optimum level modifies significantly the activity of many enzymes, plant metabolism and physiological functions (Landi et al., 2012). Furthermore, B supply in the substrate may affect the behaviour of other nutrients in plants and their behaviour is not well explained. Changes in total nutrient absorption induced by $\mathrm{B}$ concentration were reported for various nutrients and crops, such as corn (Mozafar, 1989), sunflower (Gomez-Rodriguez et al., 1981) and radish (Tariq and Mott, 2006). The inorganic composition of pepper leaves plays a key role in the fruit load and quality of pepper fruits. The absolute amount of inorganic elements not only depends on cultivar (cv) but also on soil climatic conditions, and their interaction with $\mathrm{B}$. It is obvious from the literature (Tariq and Mott, 2006) that B exerts an influence on macronutrients and on other micronutrients in plants. $B$ may affect plant response to mycorrhizal growth and increase of root surface area and length required for exploring large substrate volumes and consequently, $\mathrm{P}$ absorption rate, total $\mathrm{P}$ content and $\mathrm{P}$ use efficiency
(PUE) (Bovill et al., 2013; Huang and McDonald, 2013). Furthermore, B nutrition may affect nutrient use efficiency (NUE) in tobacco leaves (Ali et al., 2015). The effect of $\mathrm{B}$ concentration in the nutrient solution to other nutrients may be exerted via antagonism or by modifying the endogenous hormone levels such as indole 3-acetic acid (IAA), gibberellic acid (GA) and abscisic acid (ABA) (Ayvaz et al., 2012). The ABA regulates stomatal closure in peppers resulting in a reduced transpiration and decreased nutrient absorption and total nutrient content. Furthermore, high B concentration affects the response of apple in acidic or limed soils (Paparnakis et al., 2013) and also the solubility and availability of other nutrients in soil (Tariq and Mott, 2007). The chemistry of B in soil and its roles in plants differed from the other elements. Marschner (1995) reported that maintenance of optimal concentrations of mineral elements in the nutrient substrates and their absorption by plants resulted in increased productivity and better fruit quality. Another important aspect is how $\mathrm{B}$ concentration in nutrient solution affects the nutrient use efficiency (NUE) of the various nutrients (Ali et al., 2015). According to Zhang et al. (2007), plants that are efficient in absorption and utilization of minerals greatly increase the efficiency of applied fertilizer. Furthermore, Shah et al. (2014) reported that Buse efficient cotton (cvs) produced more biomass under B-deficiency. However, to our knowledge, the effect of B concentrations on total absorption and NUE of the various nutrients, which affect productivity and quality of pepper fruits has not yet clearly defined. Therefore, the objectives of this study were to determine the effect of $\mathrm{B}$ concentration in solution, exposure time of pepper plants to B and important commercial cvs (Osho, Solario, Odysseo, Arlequin) on total uptake per plant (P, K, Ca, Mg, B, Zn, Fe) and NUE (Vandamme et al., 2015) of macronutrients (P, K, Ca, Mg) and micronu- 
trients (B, Mn, Zn, Fe). More efficient values of NUE in pepper plants could reduce fertilizer costs, decrease nutrient losses and increase pepper yields.

\section{Materials and Methods}

\subsection{Plant material and growth conditions}

Four commercial pepper cvs were chosen in this study from various certified commercial F1 pepper (Capsicum annuum L.) cvs provided by the Agris Nurseries Company in northern Greece. The selected cvs were: Solario, Osho, Odysseo and Arlequin. Their choice was based on their excellent commercial and organoleptic properties. The experiment was conducted in a heated greenhouse of the Aristotle University Farm (latitude $40^{\circ} 53^{\prime} \mathrm{N}$, longitude $22^{\circ} 99^{\prime} \mathrm{E}$ ) from April to June of 2013. The climatic conditions in the greenhouse were RH $60-70 \%$, temperature $20-25^{\circ} \mathrm{C}$ and PPFD of 900 $\mu$ mole $\mathrm{m} 2 \mathrm{~s}-1$ measured at the top of plants with a quantum sensor. The experimental plants were irrigated with 50\% Hoagland nutrient solution (Hoagland and Arnon, 1938) modified to include $5 \mathrm{~B}$ concentrations, namely $0.5,1.0,2.5,5.0$ and $10.0 \mathrm{mg} \mathrm{L}^{-1}$. Every 2 days (d) each pot was irrigated with $300 \mathrm{ml}$ treatment solution and every $15 \mathrm{~d} 300 \mathrm{ml}$ of deionised water was supplied to each pot, in order to leach out any accumulated salts. The experiment included 15 plants per B treatment ( 3 plants $\mathrm{x} 5$ pots) and per $\mathrm{cv}$. that makes the total sum of plants be 300 for the four cultivars of the experiment. The experimental pots $(8 \mathrm{~L})$ were changed position on the bench to avoid positional effects on light interception or transpiration, which might affect nutrient absorption and inorganic composition of pepper plants. Three samplings of plants were conducted at $20 \mathrm{~d}, 40$ $\mathrm{d}$ and $70 \mathrm{~d}$ after the initiation of the experiment. At these dates one plant per pot was removed, separated into leaves, shoots and roots, cleaned once with tap and twice with deionised water, blotted dry and dried in a forced air oven at $68{ }^{\circ} \mathrm{C}$ for $3 \mathrm{~d}$. Afterwards, the dried plant material of each sample was milled to pass a 30 mesh screen and its ash analysed.

\subsection{Macronutrient and micronutrient analysis}

\subsubsection{Boron determination}

Boron was determined after dry ashing of $0.5 \mathrm{~g}$ dry plant material in a muffle furnace at $500^{\circ} \mathrm{C}$ for $6 \mathrm{~h}$. The ash was dissolved in $0.1 \mathrm{~N} \mathrm{HCl}$ and $\mathrm{B}$ was determined colorimetrically at $420 \mathrm{~nm}$ by the Azomethine - H method (Bingham, 1982, Mohammed et al., 2014; Wolf, 1974).

2.2.2. Macronutrients and rest of micronutrients (except B) determination

The inorganic analyses, except B, were conducted by dry ashing $0.5 \mathrm{~g}$ of plant material. Afterwards, the ash was dissolved in $3 \mathrm{ml} \mathrm{HCl}(6 \mathrm{~N})$ and each solution was diluted (16-fold) with deionised water. $\mathrm{P}$ concentration was determined by the vanado-molybdophoshate yellow colour method (Page et al., 1982) and $\mathrm{K}, \mathrm{Ca}, \mathrm{Mg}$, $\mathrm{Fe}, \mathrm{Mn}$ and $\mathrm{Zn}$ concentrations by atomic absorption spectroscopy (Perkin-Elmer 2380 Norwolk, CT, USA), using standard methods.

2.2.3. Calculation of total nutrient absorption in $\mathrm{mg}$ plant $^{-1}$ and nutrient use efficiency (NUE)

The calculation of total nutrient absorption for $\mathrm{P}, \mathrm{K}, \mathrm{Ca}$, $\mathrm{Mg}, \mathrm{B}, \mathrm{Zn}$ and $\mathrm{Fe}$ in $\mathrm{mg}$ plant $^{-1}$ was based on the total DW of leaves, shoots and roots of each plant at $20 \mathrm{~d}, 40$ $\mathrm{d}$ and $70 \mathrm{~d}$ and the corresponding values of concentrations, based on the equation: Nutrient absorption $=$ dry weight (DW) x nutrient concentration

(Zhang et al., 2007). Summation of the corresponding values for each nutrient (mg) for leaves, shoots and 
roots of the same plant gives the total absorption in mg plant ${ }^{-1}$ of each nutrient.

The calculation of NUE values of the various nutrients are based on the total DW of each plant after $70 \mathrm{~d}$ of B treatment and total absorption of each nutrient element according to the equation NUE $=$ Total DW/ Total nutrient absorption (Zhang et al., 2007). The NUE represents the mg of DW produced per mg of nutrient element absorbed. Fruit composition was excluded from calculations since our plants did not have fruits.

\subsection{Data Analysis}

The experimental layout was a completely randomized design with five $\mathrm{B}$ concentrations, $(0.5,1,2.5,5$ and $10 \mathrm{mg} \mathrm{B} \mathrm{L}^{-1}$ ), 4 cvs, 3 times of measurement (20d, 40d, 70d) and five replicates, with three plants each. The data were subjected to analysis of variance (ANOVA) using the statistical package SPSS 17.0 (SPSS Inc. Chicago, Illinois, USA). To compare the means, the Duncan's multiple range test was used at $\mathrm{P} \leq 0.05$ to establish significant differences among the treatments.

\section{Results}

\subsection{Total absorption of nutrients per plant}

Total absorption of P per plant varied from 6.7 to $3.1 \mathrm{mg}$ after $20 \mathrm{~d}$ absorption period (Figure 1A). The cv Solario absorbed more $\mathrm{P}$ per plant compared to the cvs Osho, Odysseo and Arlequin at $0.5 \mathrm{mg} \mathrm{B} \mathrm{L}^{-1}$. For B concentration $10 \mathrm{mg} \mathrm{L}^{-1}$ total $\mathrm{P}$ absorption was significantly
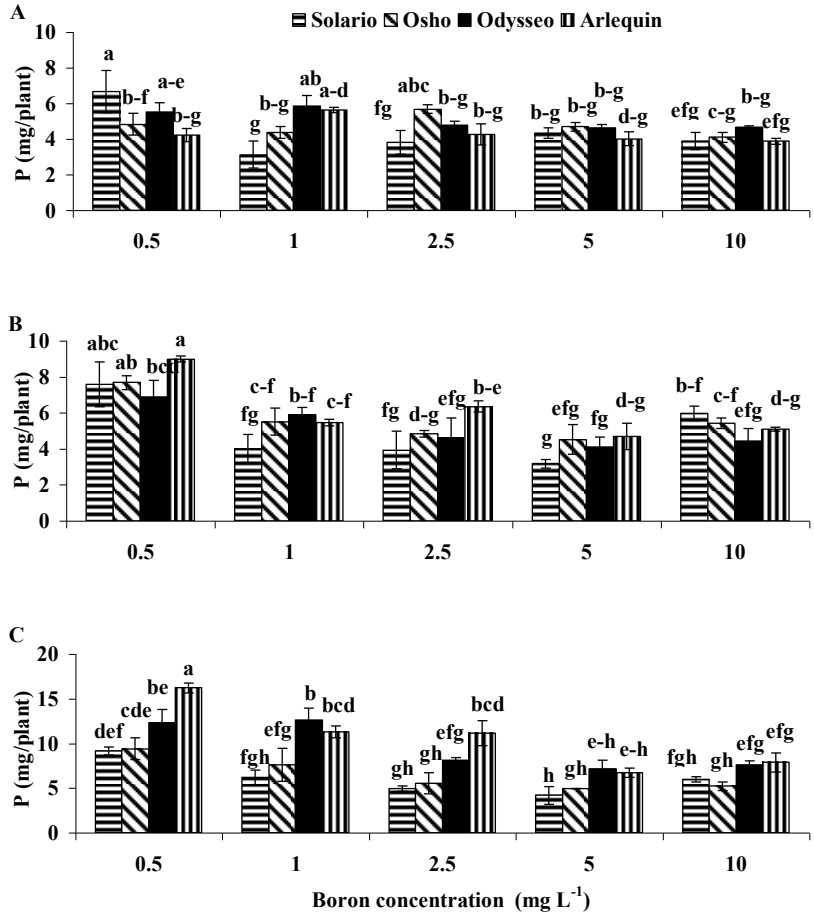

Figure 1. Total $\mathrm{P}$ absorption (mg/plant) at five $\mathrm{B}$ concentrations in four pepper cvs $(\mathrm{n}=5)$ and three sampling dates $(20 \mathrm{~d}=\mathrm{A}, 40 \mathrm{~d}=\mathrm{B}, 70 \mathrm{~d}=\mathrm{C})$. 
reduced to a value of 3.9-4.7 mg P per plant. By extending the treatment period to $40 \mathrm{~d}$ (Figure 1B), total $\mathrm{P}$ absorption at $0.5 \mathrm{mg} \mathrm{B} \mathrm{L} \mathrm{L}^{-1}$ increased to $7.6-9 \mathrm{mg}$ per plant while at $1-10 \mathrm{mg} \mathrm{B} \mathrm{L}^{-1}$ total $\mathrm{P}$ absorption was less than $7 \mathrm{mg}$ per plant, indicating inhibition of $\mathrm{P}$ absorption by B. After $70 \mathrm{~d}$ exposure time (Figure 1C) $\mathrm{P}$ absorption per plant at $0.5 \mathrm{mg} \mathrm{B} \mathrm{L}^{-1}$ reached maximum values of 9-16 $\mathrm{mg}$ per plant and minimal ones 4-8 mg per plant at $5 \mathrm{mg} \mathrm{B} \mathrm{L}^{-1}$ and $10 \mathrm{mg} \mathrm{B} \mathrm{L}^{-1}$. Among the four cvs Odysseo and Osho absorbed the greatest amount of $\mathrm{P}$ per plant.

Total $\mathrm{Ca}$ absorption per plant varied from $25 \mathrm{mg}$ to 56 $\mathrm{mg}$ after $20 \mathrm{~d}$ exposure time (Figure 2A). The cv Osho absorbed more Ca per plant compared to the cvs Solario, Odysseo and Arlequin at 2.5-10 $\mathrm{mg} \mathrm{B} \mathrm{L}^{-1}$. The same, but with greater values, was observed after a $40-\mathrm{d}$ absorption period (Figure 2B). Boron toxicity reduced Ca absorption per plant. Hence, at $70 \mathrm{~d}$ and with $2.5-10 \mathrm{mg}$ $\mathrm{B} \mathrm{L}^{-1}, \mathrm{Ca}$ absorption was significantly less than that at $0.5 \mathrm{mg} \mathrm{B} \mathrm{L}^{-1}$ for all the 4 cultivars (Figure $2 \mathrm{C}$ ).
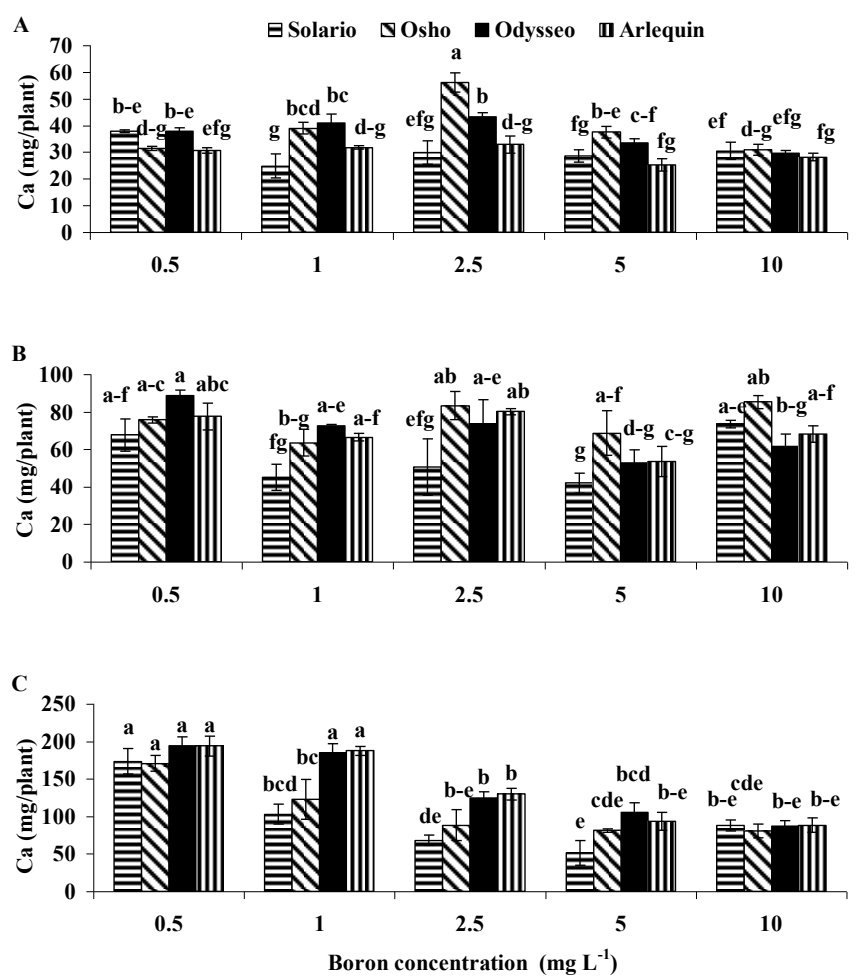

Figure 2. Total $\mathrm{Ca}$ absorption (mg/plant) at five $\mathrm{B}$ concentrations in four pepper cvs $(\mathrm{n}=5)$ and three sampling dates $(20 \mathrm{~d}=\mathrm{A}, 40 \mathrm{~d}=\mathrm{B}, 70 \mathrm{~d}=\mathrm{C})$. 
B concentration of 5-10 $\mathrm{mg} \mathrm{L}^{-1}$ at $20 \mathrm{~d}$ exposure decreased $\mathrm{K}$ absorption per plant (Figure $3 \mathrm{~A}$ ). However, after $40 \mathrm{~d}$ (Figure 3B) $\mathrm{K}$ absorption per plant was equal in all $\mathrm{B}$ treatments. The cvs with maximum $\mathrm{K}$ absorption at 0.5 and $2.5 \mathrm{mg} \mathrm{B} \mathrm{L}^{-1}$ were Odysseo and
Arlequin. When the duration of B stress increased to $70 \mathrm{~d}$ (Figure 3C), B concentrations in solution of 2.5, 5 and $10 \mathrm{mg} \mathrm{B} \mathrm{L}^{-1}$ reduced total $\mathrm{K}$ absorption to 92-197 mg per plant.
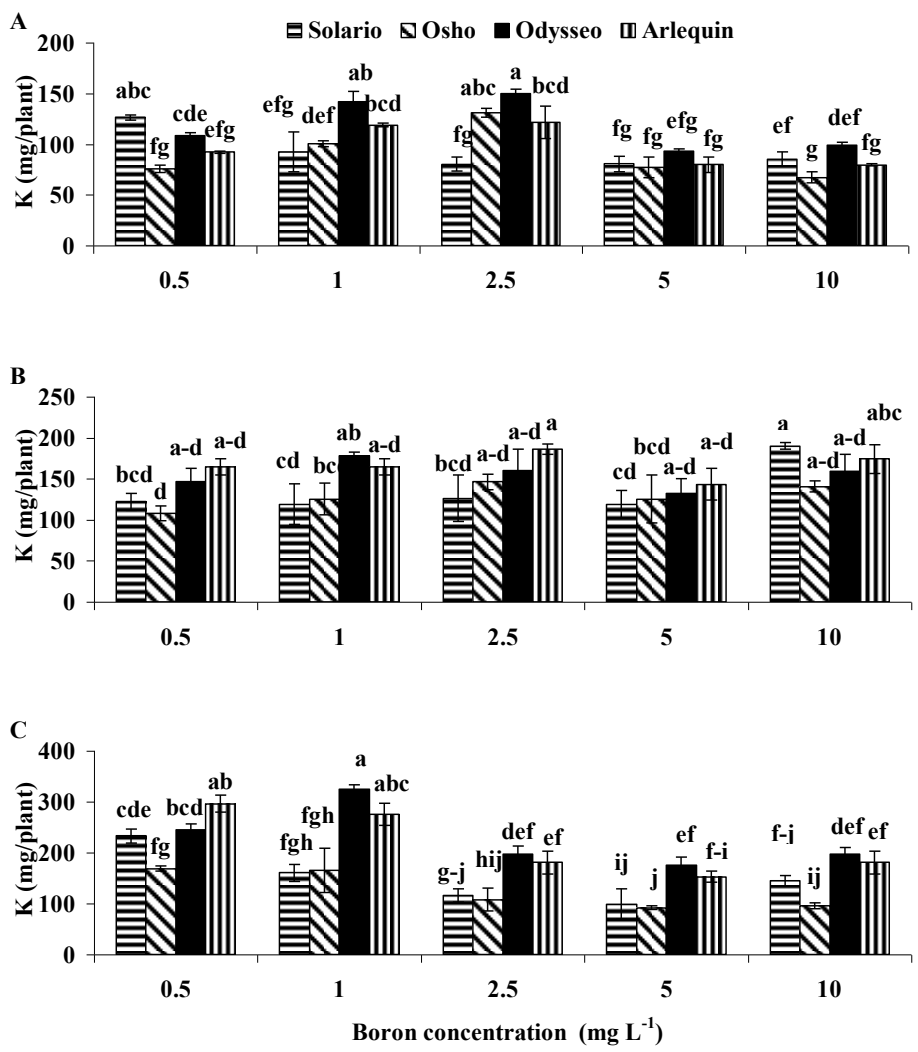

Figure 3. Total $\mathrm{K}$ absorption (mg/plant) at five $\mathrm{B}$ concentrations in four pepper cvs $(\mathrm{n}=5)$ and three sampling dates $(20 \mathrm{~d}=\mathrm{A}, 40 \mathrm{~d}=\mathrm{B}, 70 \mathrm{~d}=\mathrm{C})$.

Total $\mathrm{Mg}$ absorption (Figure 4) at $0.5-10 \mathrm{mg} \mathrm{B} \mathrm{L}^{-1}$ varied among cvs. Hence, after $20 \mathrm{~d}$ and $40 \mathrm{~d}$ exposure time (Figures 4A, 4B), the greatest Mg absorp- tion was recorded in the cv Osho at $2.5 \mathrm{mg} \mathrm{B} \mathrm{L}^{-1}$. After $70 \mathrm{~d} \mathrm{Mg}$ absorption was 41-103 mg per plant (Figure 4C). 

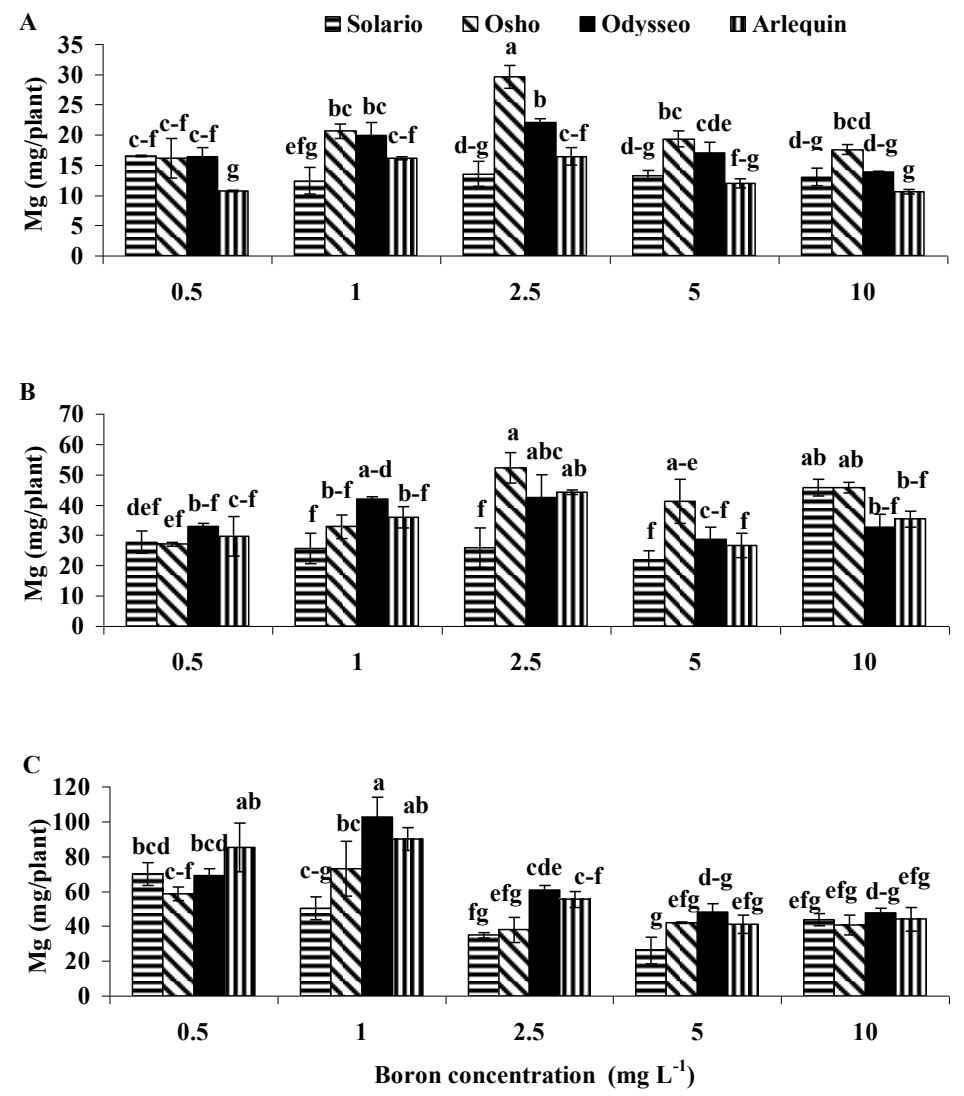

Figure 4. Total $\mathrm{Mg}$ absorption (mg/plant) at five $\mathrm{B}$ concentrations in four pepper cvs $(\mathrm{n}=5)$ and three sampling dates $(20 \mathrm{~d}=\mathrm{A}, 40 \mathrm{~d}=\mathrm{B}, 70 \mathrm{~d}=\mathrm{C})$.

Total $\mathrm{B}$ absorption varied from 0.1 to $1.0 \mathrm{mg}$ per plant after $20 \mathrm{~d}$ (Figure 5A), 0.3-1.5 mg per plant after $40 \mathrm{~d}$ (Figure 5B) and 0.6 to $4.7 \mathrm{mg} \mathrm{B}$ per plant after $70 \mathrm{~d}$ exposure time (Figure 5C). The cvs Odysseo and Arlequin absorbed more B per plant after 70 $\mathrm{d}$ of B treatment. 

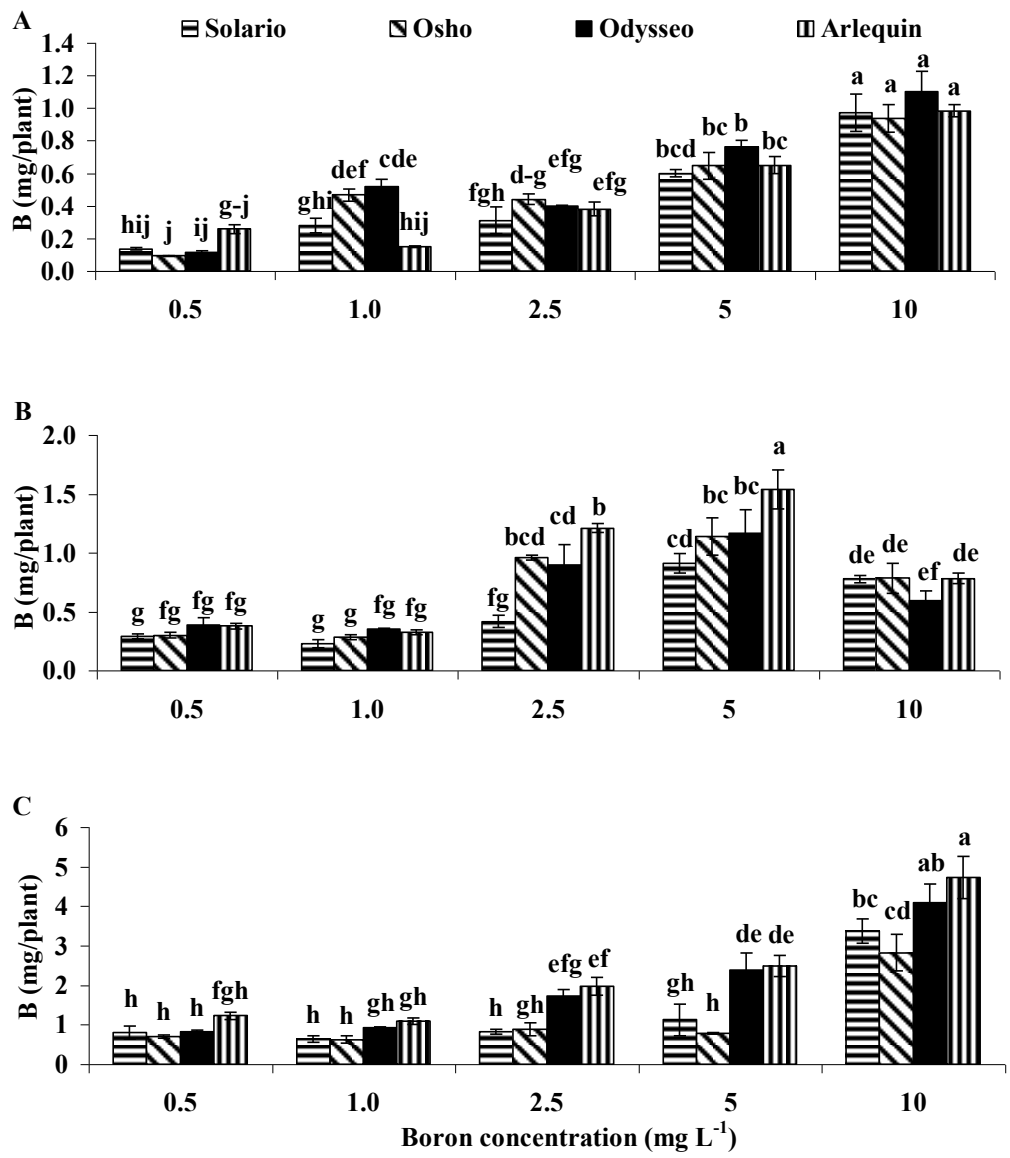

Figure 5. Total B absorption ( $\mathrm{mg} / \mathrm{plant})$ at five $\mathrm{B}$ concentrations in four pepper cvs $(\mathrm{n}=5)$ and three sampling dates $(20 d=A, 40 d=B, 70 d=C)$.

Total absorption of $\mathrm{Zn}$ per plant varied from $0.04 \mathrm{mg}$ to $0.07 \mathrm{mg}$ after $20 \mathrm{~d}$ exposure time (Figure $6 \mathrm{~A}$ ) and reduced significantly at $70 \mathrm{~d}$ (Figure 6C) $\mathrm{B}$ stress at 2.5-10 $\mathrm{mg} \mathrm{B} \mathrm{L}^{-1}$ in solution. The cv with maximum $\mathrm{Zn}$ absorption was Osho at $2.5 \mathrm{mg} \mathrm{B} \mathrm{L}^{-1}$. The total $\mathrm{Zn}$ ab- sorption per plant was $0.08-0.15 \mathrm{mg}$ at $0.5 \mathrm{mg} \mathrm{B} \mathrm{L}^{-1}$ and only $0.04-0.08$ at 5 and $10 \mathrm{mg} \mathrm{B} \mathrm{L}^{-1}$. From the tested cvs, Arlequin after $40 \mathrm{~d}$ (Figure 6B), had the maximum $\mathrm{Zn}$ absorption, which was 2 times greater than the other cvs for the same B concentration in solution. 

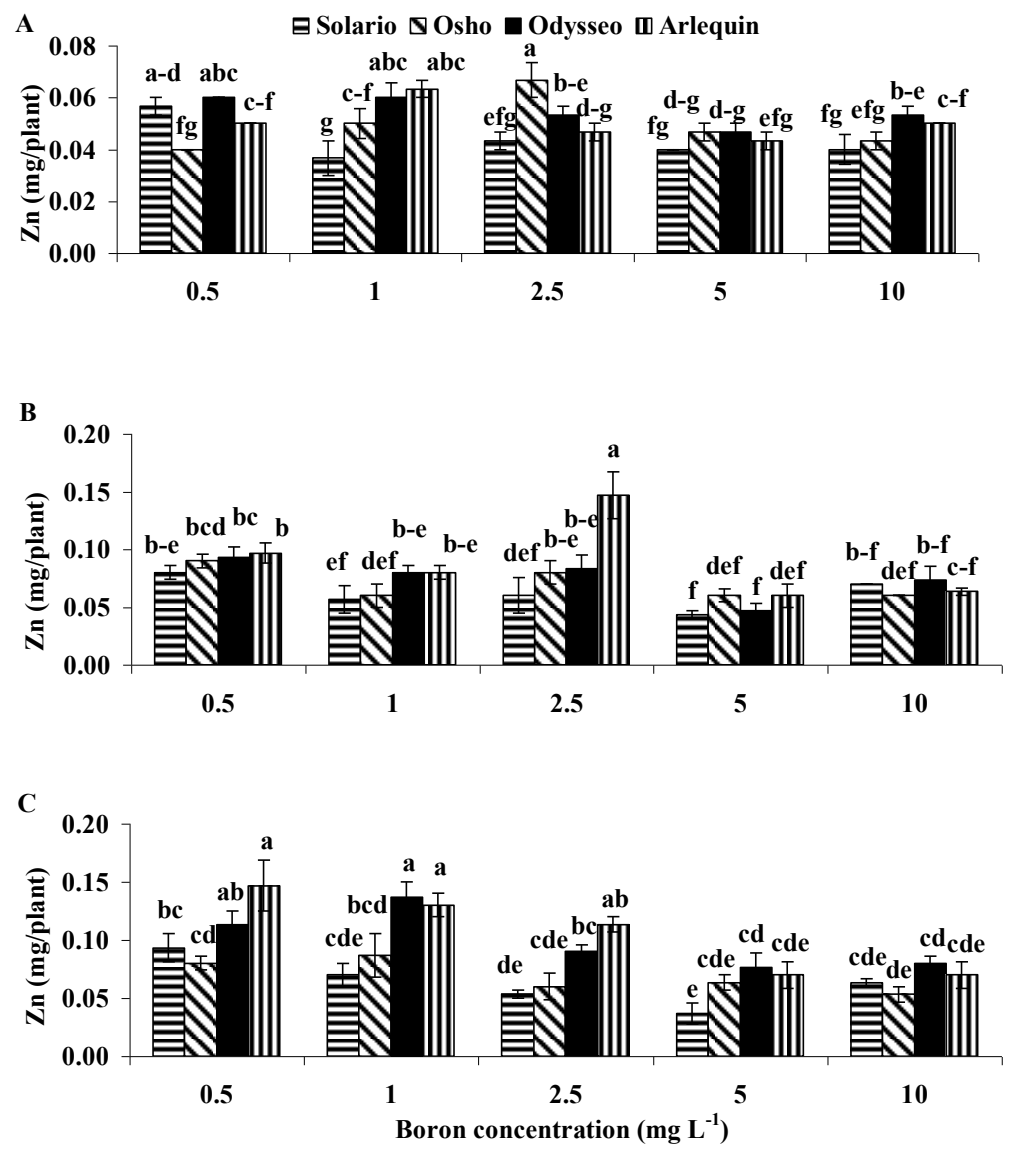

Figure 6. Total $\mathrm{Zn}$ absorption (mg/plant) at five $\mathrm{B}$ concentrations in four pepper $\mathrm{cvs}(\mathrm{n}=5)$ and three sampling dates $(20 \mathrm{~d}=\mathrm{A}, 40 \mathrm{~d}=\mathrm{B}, 70 \mathrm{~d}=\mathrm{C})$.

Total Fe absorption per plant after $20 \mathrm{~d}$ exposure ranged from 0.4 to $2 \mathrm{mg}$ per plant, with maximum absorption in Osho at $10 \mathrm{mg} \mathrm{B} \mathrm{L}^{-1}$ (Figure 7A). After $40 \mathrm{~d}$, total Fe absorption was 1.2-3.8 mg per plant. The maximum total $\mathrm{Fe}$ absorption was recorded in the cv. Arlequin at 1 and $2.5 \mathrm{mg} \mathrm{B} \mathrm{L}^{-1}$ (Figure 7B). Finally, at $70 \mathrm{~d}$ exposure the maximum $\mathrm{Fe}$ absorption was $1.6-13 \mathrm{mg}$ per plant. The $\mathrm{cv}$ with maximum Fe absorption was Arlequin at $0.5 \mathrm{mg} \mathrm{B} \mathrm{L}^{-1}$ (Figure $7 \mathrm{C}$ ). 

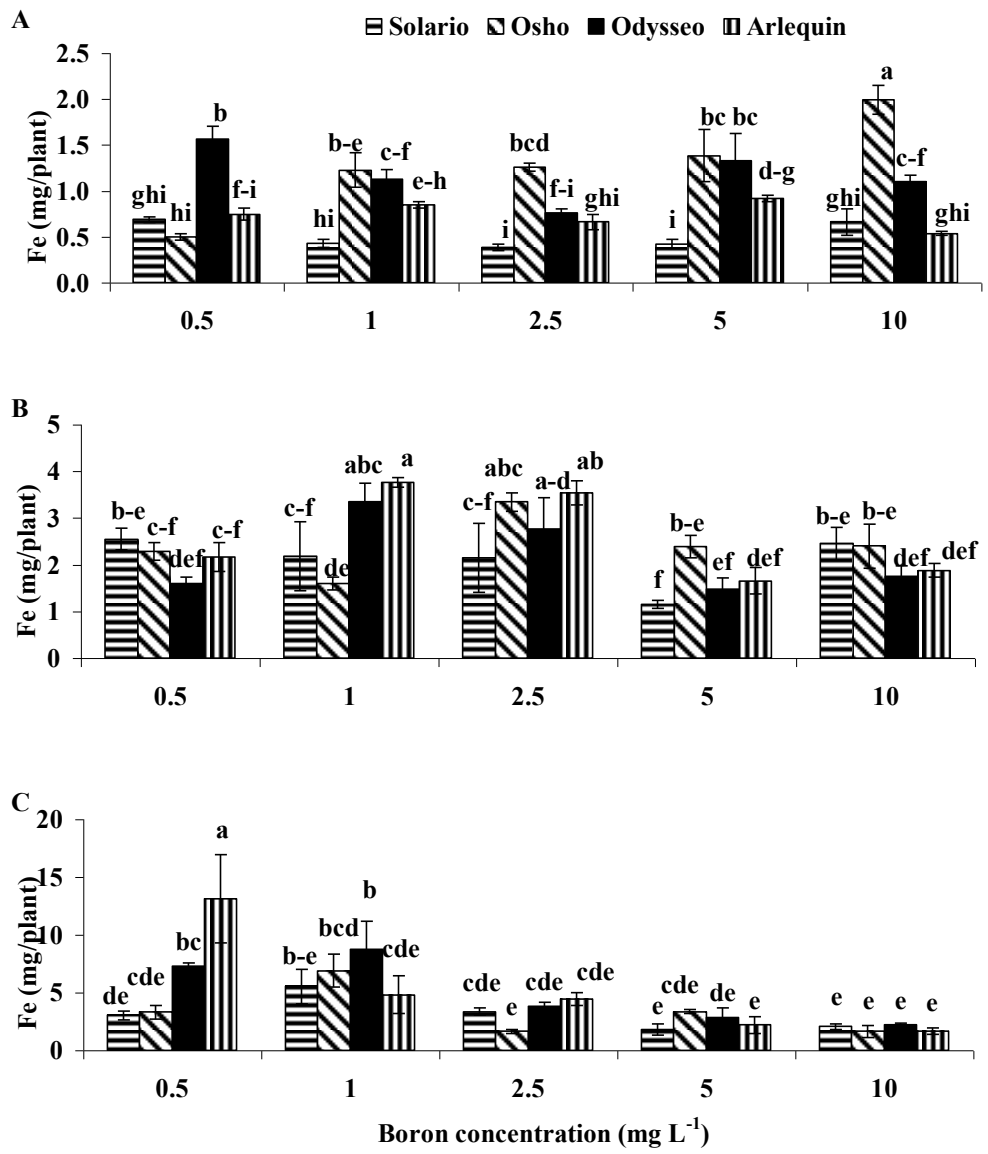

Figure 7. Total Fe absorption (mg/plant) at five B concentrations in four pepper cvs $(n=5)$ and 3 sampling dates ( $20 \mathrm{~d}$ $=A, 40 \mathrm{~d}=\mathrm{B}, 70 \mathrm{~d}=\mathrm{C})$.

After $70 \mathrm{~d}$ in B exposure a negative correlation between total absorption of $\mathrm{P}, \mathrm{Ca}, \mathrm{K}, \mathrm{Mg}, \mathrm{Zn}$, and $\mathrm{Fe}$ concentration in nutrient solution was recorded (Data are not shown). In the case of total $\mathrm{B}$ absorption this relationship was positive at $20 \mathrm{~d}$ and $70 \mathrm{~d}$ exposure time

\subsection{Nutrient use efficiency (NUE)}

Calculation of NUE (mg of nutrient element $\mathrm{g}^{-1} \mathrm{DW}$ ) indicated significant differences among nutrients concerning their NUE (Table 1) in four pepper cvs grown at five B concentrations. The PUE varied from 0.960 to 1.680 depending on $\mathrm{cv}$ and $\mathrm{B}$ concentration. The respective values for the rest nutrients are 20.666-33.077 for $\mathrm{K}, 11.068-27.338$ for $\mathrm{Ca}, 5.714-12.744$ for $\mathrm{Mg}$, 0.027-0.050 for Mn, 0.009-0.014 for Zn, 0.087-0.838 for B and 0.290-1.298 for Fe. By increasing B concentration in solution more $\mathrm{B}$ required to produce $1 \mathrm{~g} \mathrm{DW}$ of pepper plant. The maximum NUE values for $\mathrm{P}$ and $\mathrm{K}$ (less $\mathrm{P}$ and $\mathrm{K}$ required per $\mathrm{g} \mathrm{DW}$ produced) were recorded in Solario and Osho with $5 \mathrm{mg} \mathrm{B} \mathrm{L}^{-1}$ and for $\mathrm{Ca}$ in Solario. BUE was maximum (less $\mathrm{B}$ required per 
g DW produced) for Solario, Osho and Odysseo at 0.5 $\mathrm{mg} \mathrm{B} \mathrm{L}{ }^{-1}$. In the case of $\mathrm{Fe}, \mathrm{B}$ concentration effect in all cvs was variable concerning Fe use efficiency (FeUE).
The effect of B concentration and cv was variable also in the case of Mg use efficiency (MgUE), Mn use efficiency (MnUE) and $\mathrm{Zn}$ use efficiency (ZnUE).

Table 1. Nutrient use efficiency (mg nutrient $\mathrm{g}^{-1} \mathrm{DW}$ ) of macronutrients (P, $\mathrm{K}, \mathrm{Ca}, \mathrm{Mg}$ ) and micronutrients ( $\mathrm{Mn}, \mathrm{Zn}$, $\mathrm{B}, \mathrm{Fe}$ ) in four pepper cultivars as affected by five $\mathrm{B}$ concentrations in the substrate. Means with the same letter in the same column are not significantly different at $\mathrm{P} \leq 0.05$ (Duncan's multiple range test).

\begin{tabular}{|c|c|c|c|c|c|c|c|c|c|}
\hline Treatments & Cultivar & $\mathrm{P}$ & $\mathrm{K}$ & $\mathrm{Ca}$ & $\mathrm{Mg}$ & $\mathrm{Mn}$ & $\mathrm{Zn}$ & B & $\mathrm{Fe}$ \\
\hline $\mathrm{mg} \mathrm{B} \mathrm{L}^{-1}$ & & \multicolumn{8}{|c|}{ Nutrient use efficiency - 70 days } \\
\hline \multirow[t]{4}{*}{0.5} & Solario & $1.120 \mathrm{cde}$ & 28.567 b-e & $21.115 \mathrm{~cd}$ & 8.532 b-f & 0.037 e-h & $0.011 \mathrm{~cd}$ & $0.096 \mathrm{~g}$ & $0.369 \mathrm{e}$ \\
\hline & Osho & $1.492 \mathrm{ab}$ & $27.162 \mathrm{c}-\mathrm{f}$ & $27.338 \mathrm{a}$ & $9.365 \mathrm{bc}$ & $0.050 \mathrm{bc}$ & $0.013 \mathrm{a}-\mathrm{d}$ & $0.112 \mathrm{fg}$ & 0.522 cde \\
\hline & Odysseo & $1.538 \mathrm{ab}$ & $30.678 \mathrm{abc}$ & $24.264 \mathrm{~b}$ & $8.621 \mathrm{~b}-\mathrm{f}$ & $0.047 \mathrm{bcd}$ & $0.014 \mathrm{ab}$ & $0.103 \mathrm{fg}$ & $0.916 \mathrm{abc}$ \\
\hline & Arlequin & $1.680 \mathrm{a}$ & $30.244 \mathrm{a}-\mathrm{d}$ & 19.752 cde & $8.550 \mathrm{~b}-\mathrm{f}$ & $0.052 \quad \mathrm{~b}$ & $0.014 \mathrm{ab}$ & 0.125 efg & $1.298 \mathrm{a}$ \\
\hline \multirow[t]{4}{*}{1} & Solario & $1.107 \mathrm{cde}$ & 28.812 b-e & $18.365 \mathrm{efg}$ & $8.936 \mathrm{bcd}$ & $0.037 \mathrm{e}-\mathrm{h}$ & $0.012 \mathrm{bcd}$ & $0.115 \mathrm{fg}$ & $0.971 \mathrm{ab}$ \\
\hline & Osho & $1.299 \mathrm{bcd}$ & 28.042 b-f & $21.483 \mathrm{c}$ & $12.744 \mathrm{a}$ & $0.063 \mathrm{a}$ & $0.015 \mathrm{a}$ & $0.115 \mathrm{fg}$ & $1.256 \mathrm{a}$ \\
\hline & Odysseo & $1.180 \mathrm{cde}$ & $30.654 \mathrm{abc}$ & $17.372 \mathrm{e}-\mathrm{i}$ & $9.607 \mathrm{~b}$ & $0.043 \mathrm{c}-\mathrm{f}$ & $0.013 \mathrm{a}-\mathrm{d}$ & $0.087 \mathrm{~g}$ & $0.821 \mathrm{bcd}$ \\
\hline & Arlequin & $1.117 \mathrm{cde}$ & $27.124 \mathrm{c}-\mathrm{f}$ & 18.608 def & 8.864 bcd & $0.039 \mathrm{~d}-\mathrm{g}$ & $0.013 \mathrm{a}-\mathrm{d}$ & $0.107 \mathrm{fg}$ & $0.474 \mathrm{de}$ \\
\hline \multirow[t]{4}{*}{2.5} & Solario & $1.026 \mathrm{de}$ & $23.895 \mathrm{fgh}$ & $14.088 \mathrm{j}$ & $7.232 \mathrm{fg}$ & 0.032 ghi & $0.011 \mathrm{de}$ & $0.170 \mathrm{~d}-\mathrm{g}$ & $0.713 \mathrm{~b}-\mathrm{e}$ \\
\hline & Osho & $1.070 \mathrm{cde}$ & $20.666 \mathrm{hi}$ & $16.817 \mathrm{f}-\mathrm{j}$ & $7.336 \mathrm{efg}$ & 0.045 b-e & $0.011 \mathrm{~cd}$ & $0.174 \mathrm{~d}-\mathrm{g}$ & $0.356 \mathrm{e}$ \\
\hline & Odysseo & $1.031 \mathrm{de}$ & $25.122 \mathrm{efg}$ & $15.813 \mathrm{f}-\mathrm{j}$ & $7.724 \mathrm{~d}-\mathrm{g}$ & $0.037 \mathrm{e}-\mathrm{h}$ & $0.012 \mathrm{~cd}$ & 0.218 def & $0.494 \mathrm{de}$ \\
\hline & Arlequin & $1.362 \mathrm{bc}$ & $21.711 \mathrm{ghi}$ & $15.655 \mathrm{~g}-\mathrm{j}$ & $6.650 \mathrm{gh}$ & $0.043 \mathrm{c}-\mathrm{f}$ & $0.014 \mathrm{abc}$ & $0.237 \mathrm{de}$ & 0.547 cde \\
\hline \multirow[t]{4}{*}{5} & Solario & $0.960 \mathrm{e}$ & 21.745 ghi & $11.068 \mathrm{k}$ & $5.714 \mathrm{~h}$ & $0.027 \quad \mathrm{i}$ & $0.009 \mathrm{e}$ & $0.241 \mathrm{~d}$ & $0.397 \mathrm{e}$ \\
\hline & Osho & $0.964 \mathrm{e}$ & $17.828 \mathrm{i}$ & $15.853 \mathrm{f}-\mathrm{j}$ & 8.196 b-f & $0.039 \mathrm{~d}-\mathrm{g}$ & $0.012 \mathrm{~cd}$ & $0.152 \mathrm{~d}-\mathrm{g}$ & $0.659 \mathrm{~b}-\mathrm{e}$ \\
\hline & Odysseo & $1.077 \mathrm{cde}$ & $26.446 \mathrm{def}$ & $15.865 \mathrm{f}-\mathrm{j}$ & $7.226 \mathrm{fg}$ & $0.041 \mathrm{~d}-\mathrm{g}$ & $0.012 \mathrm{~cd}$ & $0.355 \mathrm{c}$ & $0.410 \mathrm{de}$ \\
\hline & Arlequin & $1.091 \mathrm{cde}$ & 24.770 e-h & 14.994 hij & $6.591 \mathrm{gh}$ & $0.034 \mathrm{f}-\mathrm{i}$ & $0.011 \mathrm{de}$ & $0.402 \mathrm{c}$ & $0.339 \mathrm{e}$ \\
\hline \multirow[t]{4}{*}{10} & Solario & $1.028 \mathrm{de}$ & 24.790 e-h & $15.107 \mathrm{ijk}$ & $7.467 \mathrm{~d}-\mathrm{g}$ & $0.030 \mathrm{hi}$ & $0.011 \mathrm{de}$ & $0.579 \mathrm{~b}$ & $0.353 \mathrm{e}$ \\
\hline & Osho & $1.147 \mathrm{cde}$ & $21.293 \mathrm{ghi}$ & 17.626 e-h & $8.832 \mathrm{~b}-\mathrm{e}$ & 0.044 cde & $0.012 \mathrm{~cd}$ & $0.632 \mathrm{~b}$ & $0.351 \mathrm{e}$ \\
\hline & Odysseo & 1.274 b-e & $33.077 \mathrm{a}$ & $14.575 \mathrm{ij}$ & $7.931 \mathrm{c}-\mathrm{g}$ & 0.042 c-f & $0.013 \mathrm{a}-\mathrm{d}$ & $0.684 \mathrm{~b}$ & $0.367 \mathrm{e}$ \\
\hline & Arlequin & $1.386 \mathrm{abc}$ & $31.950 \mathrm{ab}$ & $15.774 \mathrm{f}-\mathrm{j}$ & $7.723 \mathrm{~d}-\mathrm{g}$ & $0.043 \mathrm{c}-\mathrm{f}$ & $0.012 \mathrm{a}-\mathrm{d}$ & $0.838 \mathrm{a}$ & $0.290 \mathrm{e}$ \\
\hline
\end{tabular}

\section{Discussion}

The interactions of B with other plant nutrients are very complex and their effect is antagonistic or synergistic, depending on $\mathrm{cv}$ and growth substrate. Increased $\mathrm{B}$ levels in nutrient solution reduced significantly total $\mathrm{P}$ absorption per pepper plant and increased PUE at 5 $\mathrm{mg} \mathrm{B} \mathrm{L}{ }^{-1}$ in Solario and Osho, indicating dependence on $\mathrm{cv}$ and $\mathrm{B}$ concentration in solution. Improved PUE lead either to higher crop production with equal $\mathrm{P}$ absorption or to a decrease of $\mathrm{P}$ depletion of soils (Vandamme et al., 2015). The main mechanism of the movement of $\mathrm{P}$ from soil to roots is diffusion. The absorption of $\mathrm{P}$ by roots is limited by the rate of $\mathrm{P}$ diffusion to roots rather than $\mathrm{P}$ absorption across root plasmalemma (Arruda et al., 2016). Since the quantity of $\mathrm{P}$ absorbed by roots does not recycle back to rooting medium the improvement of PUE requires exploitation of genotypic variation in PUE (Simpson et al., 2011). Therefore, root exploitation of the nutrient substrate is critical for PUE (Gamuyao et al., 2012). In order to maximize PUE, plants modify the rooting architecture producing a more branched root system by reduction of primary root growth and increasing lateral root density (Huang and Mc Donald, 2013). Possibly this happens in our experiment due to $\mathrm{B}$ concentration affecting root growth pattern. In pure hydroponic culture, there is little correlation between genotypic PUE in soil grown plants vs hydroponically grown plants (Bovill et al., 2013). Since, our experiment was conducted in a solid 
medium (1:1 sand:perlite) which resembles more to soil, the PUE value of our experiment is closer to the expected PUE value under field conditions.

Numerous studies have also investigated genotypic variation for PUE (Rose et al., 2016). Cultivating pepper plants in a sand/perlite (1:1) substrate appears to be a valid approach for studying NUE and find genotypic differences. Furthermore, this method is fast and of low cost.

Total K uptake was a function of B concentration in the substrate, duration of $B$ stress and genotypic variation of cvs employed. In high B treatments, total $\mathrm{K}$ absorption decreased due possibly to reduced plant or root growth and to inhibitory effect of high B. Again, the optimum $\mathrm{B}$ concentrations for peppers are $0.5 \mathrm{mg}$ $\mathrm{B} \mathrm{L}^{-1}$ and $1 \mathrm{mg} \mathrm{B} \mathrm{L}^{-1}$ at $70 \mathrm{~d}$, time after which pepper plants start bearing fruits. However, increased B concentrations ( $5 \mathrm{mg} \mathrm{B} \mathrm{L}^{-1}$ ) increased KUE in the $\mathrm{cv}$ Osho. It is therefore important in agricultural practice for achievement of the highest KUE to control B concentration in soil or nutrient solution. Soil factors and plant mechanisms that modify genotypic differences in NUE in plants grown in various B levels include: i) diffusion, mass flow and ionic concentration ii) enzyme secretion iii) nutrient mobility and transport across endodermis iv) nutrient accumulation and utilization and v) soil and environmental factors, such as soil solution, composition and light intensity. A genotypic difference was recorded among the tested pepper cvs concerning total $\mathrm{Ca}$ absorption per plant. The decrease of total $\mathrm{Ca}$ absorption is possibly ascribed to B toxicity on cell membranes and to ABA production (Ayvaz et al., 2012) resulting in stomatal closure. A reduced transpiration rate due to $\mathrm{B}$ toxicity is probably the responsible factor for the decreased $\mathrm{Ca}$ absorption and transport to tops of pepper plants. The same, as in the case of $\mathrm{Ca}$, applies to total $\mathrm{Mg}$ absorption. However, total $\mathrm{Mg}$ absorption per plant is only $66 \%$ of that of total $\mathrm{Ca}$. The Ca use efficiency
(CaUE) was increased at high B concentrations (5 $\mathrm{mg}$ and $10 \mathrm{~B} \mathrm{~L}^{-1}$ ) while MgUE increased at lower B concentrations depending on cvs, indicating a different mechanism.

Total B absorption per plant showed a significantly linear and positive relationship with $\mathrm{B}$ concentration in the substrate after $20 \mathrm{~d}$ and $70 \mathrm{~d}$ of treatment. This indicates that the accumulation of B in pepper plants depends not only on the levels of $\mathrm{B}$ in the rooting media but also on the $\mathrm{cv}$ employed and duration of treatment. Pepper leaves contain more B than roots, a result which agrees with others for Citrus (Papadakis et al., 2004). Boron is transported to leaves via the transpiration stream and its remobilization from leaves to other organs is limited. However, information regarding the effect of $\mathrm{B}$ concentration in solution on total absorption per plant and transport of macronutrients and micronutrients in peppers is scant. On the contrary, in maize plants by increasing B concentration in the nutrient solution the concentration of other nutrients was changed in the leaves as well as in roots (Mozafar, 1989). The lack of data for pepper in this aspect indicates that our results are a novelty in the area of plant nutrition of peppers.

Furthermore, our data indicated that B toxicity may create $\mathrm{Fe}$ deficiency in pepper plants, which is concerned with the oxidation reduction equilibrium in cells and reduced plant growth and root size. High levels of B after $70 \mathrm{~d}$ in culture antagonized Fe absorption but $10 \mathrm{mg} \mathrm{B} \mathrm{L}^{-1}$ increased FeUE (Table 1). Almost equal $\mathrm{Zn}$ concentrations were found in the leaves and roots of pepper plants (data are not shown) suggesting that $\mathrm{Zn}$ was equally distributed or not translocated from tops to roots and this may be ascribed to B concentration effects to $\mathrm{Zn}$ mobility. Total $\mathrm{Zn}$ absorption per plant was minimum, compared to other micronutrients and B toxicity affected more total $\mathrm{Zn}$ absorption per plant than the other micronutrients. By comparing $\mathrm{Zn}$ concentration of leaves with total $\mathrm{Zn}$ absorption per plant it was 
found that $\mathrm{Zn}$ concentration of leaves (data not shown) was increased, as B concentration in solution increased. This value creates artifacts about the $\mathrm{Zn}$ levels in the plant to judge for nutrient $\mathrm{Zn}$ deficiency. On the contrary total $\mathrm{Zn}$ absorption per plant gives us a clear view of the physiological condition of pepper plants concerning their $\mathrm{Zn}$ level and is therefore more valid than $\mathrm{Zn}$ concentration of leaves, as a prognostic tool for $\mathrm{Zn}$ deficiency. Since differences are mainly ascribed to the different distribution of nutrients in tops or roots this is avoided by studying inorganic composition of the whole plant as a unit. Among micronutrients, Zn deficiency is one of the most widespread nutritional disorders in many plants including peppers and B toxicity and $\mathrm{Zn}$ deficiency are closely related with each other. Furthermore, $\mathrm{ZnUE}$ is positively correlated with the activity of the enzyme Cu/Zn COD (Cakmak et al., 1997). Santra et al. (1989) reported that B may function both within the plant and also in the nutrient medium, by modifying the absorption of nutrient elements. Since B affects total absorption of other elements in pepper, these results suggest that B may also regulate the availability of ions of other nutrients in the rooting substrate. Boron participates in physiological and biochemical processes and it is possible to affect the utilization of other nutrient elements and this relationship is very complex. In the literature information concerning the effect of $\mathrm{B}$ on the availability and absorption of other nutrients for pepper plants does not exist. The efficiency of fertilizers can be optimized by using the most appropriate fertilization procedure (Roberts, 2008). Therefore, the decrease of NUE in most nutrients in pepper plants due to high $\mathrm{B}$ takes place because pepper plants are unable to adjust to the physiological changes arising from B level in soil or nutrient substrate. Increasing NUE in pepper plants enhances production and quality of fruits and reduces fertilization cost. Much can be achieved by selecting nutrient efficient genotypes and to incorporate these in breeding programs. However, the little progress of nutritional genetics of plants and the difficulty in identification of nutrienticient genotypes are responsible for the lack of progress in breeding cvs with high NUE. Genetic variability has been reported in order to explain the differences in NUE and nutrient absorption. Increasing the nutrient content in pepper leaves and shoots and subsequently to fruits due to phloem transport, is the most efficient means to supply nutrient elements to people which are prone to develop nutrient deficiencies or nutrient imbalance. Agricultural management methods are another means to improve the nutrient absorption by pepper plants, and their subsequent phloem transport to pepper fruits. Furthermore, molecular techniques could be used in the future to genetically affect pepper plants in order to increase bioavailable concentration of nutrients. This includes total nutrient absorption per plant by roots, increased NUE, translocation of nutrients from roots to shoots and increased phloem transport of nutrient elements from leaves to pepper fruits. The mechanisms that regulate these processes in pepper plants are not known and further research is necessary in order to find these mechanisms and the genes involved in their regulation. Generally, the high concentrations of added B in nutrient solution exerted interactive effects on the total absorption of all nutrients, which decreased at $70 \mathrm{~d}$, while total $\mathrm{B}$ absorption increased by increasing levels of $\mathrm{B}$ in the nutrient solution. At low B concentration ( 0.5 and $1 \mathrm{mg} \mathrm{B} \mathrm{L}^{-1}$ ) the total absorption per plant of each nutrient, except $\mathrm{B}$, was greater than in the rest concentrations and this was cv dependent. Therefore, for optimum plant growth and maximum absorption of nutrients $\mathrm{B}$ concentration in nutrient solution in pepper culture should not exceed $1 \mathrm{mg} \mathrm{B} \mathrm{L}{ }^{-1}$.

\section{Conclusions}

Total nutrient absorption is a function of $\mathrm{B}$ concentration in nutrient solution, duration of treatment and 
pepper cv employed. At concentrations of 2.5, 5 and $10 \mathrm{mg} \mathrm{B} \mathrm{L}^{-1}$ and after exposure for $70 \mathrm{~d}$ the total absorption of $\mathrm{P}, \mathrm{K}, \mathrm{Ca}, \mathrm{Mg}, \mathrm{Zn}$ and $\mathrm{Fe}$ was significantly reduced in comparison to $0.5 \mathrm{mg} \mathrm{B} \mathrm{L^{-1 }}$ treatment, while the total $\mathrm{B}$ absorption increased. Furthermore, high B (5 mg B L $\left.{ }^{-1}\right)$ in the substrate increased PUE, KUE and CaUE for certain cvs and did not affect MgUE, MnUE and ZnUE.

\section{Acknowledgements}

We would like to express our sincere gratitude to Agris Advancing Horticulture S.A for kindly providing the pepper plants and also, our sincere thanks to S. Kouti and V. Tsakiridou for technical assistance in the preparation of nutrient solutions. The authors gratefully acknowledge the financial support of the Aristotle University of Thessaloniki.

\section{References}

Ali, F., Ali, A., Gul, H., Sharif, M., Sadiq, A., Ahmed, A., Ullah, A., Mahar, A., Kalhoro, S.A. 2015. Effect of boron soil application on nutrients efficiency in tobacco leaf. Am. J. Plant. Sci. 6, 13911400 .

Arruda, B., Rodrigues, M., Soltangheisi, A., Richardson, A.E., Andreote, F.D., Pavinato, P.S. 2016. Biological and morphological traits of sugarcane roots in relation to phosphorus uptake. J. Soil Sci. Plant Nutr. 16, 901-915.

Ayvaz, M., Koyuncu, M., Guven, A., Fagerstedt, K. 2012. Does boron affect hormone levels of barley cultivars? Eurasia J. Biosci. 6, 113-120.

Bingham., F.T. 1982. Boron. Chemical and microbiological properties. In: Page, A.L., Miller R.H., Keeney D.R. (Eds.), Methods of Soil Analysis., Part 2. Madison, Wisconsin: ASA, pp: 431-437.
Bovill, W.D., Huang, C.Y., McDonald, G.K. 2013 Genetic approaches to enhancing phosphorus-use efficiency (PUE) in crops: challenges and directions. Crop Pasture Sci. 64, 179-198.

Bruna, A., Marcos R., Amin, S., Alan, E.R., Fernando D.A., Paulo S.P. 2016. Biological and morphological traits of sugarcane roots in relation to phosphorus uptake. J. Soil Sci. Plant Nutr. 16, 901-915.

Cakmak, I., Ekiz, H., Yilmaz, A., Torum, B., Koleli, N., Gultekin, I. 1997. Differential response of rye, triticale, bread and durum wheats to zinc deficiency in calcareous soils. Plant Soil. 188, 1-10.

Gamuyao, R., Chin, J.H., Pariasca-Tanaka, J., Pesaresi, P., Catausan, S., Dalid, C., Slamet-Loedin, I., Tecson-Mendoza, E.M., Wissuwa, M., Heuer, S. 2012. The protein kinase Pstoll from traditional rice confers tolerance of phosphorus deficiency. Nature. 488, 535-539.

Gomez-Rodriguez, M.V., Gomez-Ortega, M., Alvarez-Tinaut, M.C. 1981. Boron, copper, iron, manganese and zinc contents in leaves of flowering sunflower plants (Helianthus annuus L.) grown with different boron supplies. Plant Soil. 62, 461-464.

Hoagland, D.R., Arnon, D. I. 1938. The water culture method for growing plants without soil. Calif. Agric. Exp. Stn Bull. 347, 1-39.

Huang, C.Y., McDonald, G. 2013. Genetic approaches to enhancing phosphorus use efficiency (PUE) in crops: Challenges and directions. Crop Pasture Sci. 64, 173-198.

Landi, L.M., Degl'Innocenti, E., Pardossi, A., Guidi, L. 2012. Antioxidant and photosynthetic responses in plants under boron toxicity: A review. Am. J. Agric. Biol. Sci. 7, 255-270.

Marschner, H. 1995. Mineral nutrition of higher plants, 379-396. London: Academic Press. 
Mohammed, Y.I., Garba, K., Umar, S. 2014. Analytical determination of boron in irrigation water using azomethine-H: Spectrophotometry. IOSRJAC. 7, 47-51.

Mozafar, A. 1989. Boron effect on mineral nutrients of maize. Agron. J. 81, 285-290.

Nable, R.O., Bañuelos, G.S., Paull, J.G. 1997. Boron toxicity. Plant Soil. 193, 181-198.

Namiki, M. 1990. Antioxidants/antimutagens in food. Food Science and Nutrition. 29, 273-300.

Ogunlade, I., Alebiosu, A.A., Osasona, A.I. 2012. Proximate, mineral composition, antioxidant activity, and total phenolic content of some pepper varieties (Capsicum species). J. Biol. Chem. Sci. 6, 2221-2227.

Page, A.L., Miller, H.R., Keeney, R.D. 1982. Chemical and microbiological properties. In: Methods of soil analysis, 1159 p. Vol. 2. Madison, Wisconsin: SSSA

Papadakis, I.E., Dimassi, K.N., Bosabalidis, A.M., Therios, I.N., Giannakoula, A. 2004. Boron toxicity in Clementine mandarin plants grafted on two rootstocks. Plant Sci. 166, 539-547.

Paparnakis, A., Chatzissavvidis, C., Antoniadis, V. 2013. How apple responds to boron excess in acidic and limed soil. J. Soil Sci. Plant Nutr. 7, 787-796.

Roberts, T.L. 2008. Improving nutrient use efficiency. Turk. J. Agric. For. 32, 177-182.

Rose, T.J., Mori, A., Julia, C.C., Wissuwa, M. 2016. Screening for internal phosphorus utilisation efficiency: comparison of genotypes at equal shoot $\mathrm{P}$ content is critical. Plant Soil. 401, 79-91.

Santra, G.H., Das, D.K., Mandal, B.K. 1989. Relationship of boron with iron, manganese, copper and zinc with respect to their availability in rice soil. Environment and Ecology. 7, 874-877.
Sarafi, E., Siomos, A., Tsouvaltzis, P., Chatzissavvidis, C., Therios, I. 2017. Boron toxicity effects on grafted and non-grafted pepper (Capsicum annuит L.) plants. J. Soil. Sci. Plant Nutr. 17, 441-460.

Shah, J.A., Zia-ul-hassan, Rajpar, I., Sial, M.A. 2014. Evaluating boron-use-efficiency of twenty cotton genotypes of Pakistan. Pak. J. Agri. Eng. Vet. Sci. 30, 147-158.

Simpson, R.J., Obeeson, A., Culvenor, R.A., Ryan, M.H., Veneklaas, E. J., Lambers, H., Lynch, J.P., Ryan, P.R., Delhaize, E., Smith, F.A., Smith, S.E., Harvey, P.R., Richardson, A.E. 2011. Strategies and agronomic interventions to improve the phosphorus - use efficiency of farming systems. Plant Soil. 349, 89-120.

Tariq, M, Mott, C.J.B. 2006. Effect of boron supply on the uptake of micronutrients by radish (Raphanus sativus L.). J. Agr. Biol. Sci. 1, 1-8.

Tariq, M, Mott, C.J.B. 2007. Effect of boron and the behaviour of nutrients in soil-plants systems- A review. Asian J. Plant Sci. 6, 195-202.

Vandamme, E., Rose, T., Saito, K., Jeang, K., Wissuma, M. 2015. Integration of $P$ acquisition efficiency, $\mathrm{P}$ utilization efficiency and low grain $\mathrm{P}$ concentration into P-efficient rice genotypes to specific target environments. Nutr. Cycl. Agroecosyst. 104, 413-427.

Zhang, Z., Tian, X., Duan, L., Wang, B., He, Z., Zi, Z. 2007. Differential responses of conventional and bt-transgenic cotton to potassium deficiency. J. Plant Nutr. 30, 659-670.

Wolf, R. 1974. Improvements in the Azomethine-H method for the determination of boron Comm. Soil Sci. Plant Anal. 5, 39-44. 